\title{
PERKEMBANGAN REGULASI DIRI ANAK USIA DINI: PERANAN KEMAMPUAN BERBAHASA DAN REGULASI DIRI PADA PEMBELAJARAN
}

\author{
Naili Sa'ida \\ PG PAUD Universitas Muhammadiyah Surabaya \\ E-mail: nailisaida@ fkip.um-surabaya.ac.id
}

Received August 2018, Accepted September 2018, Published October 2018

\begin{abstract}
This study aims to describe the development of self-regulation of children aged 4-5 years at Kindergarten Dhamawanita Persatuan Pucang Jajar. This study is a qualitative case study in children aged 4-5 years. Data analysis techniques use the model proposed by Miles and Huberman which consists of 3 stages: data reduction, data display, and verification. The research were use multi technique to collect the data use the observation, interviews, and documentation. The results showed that the development of self-regulation developed simultaneously with language skills. Language can really play an important role in determining how children regulate their thoughts, emotions, and behavior. Language facilitates the internalization of children's social structures and rules through their interaction in the social world around them. When children interact with others, their understanding of other people's perspectives and expectations is expanded. This perspective shows that language helps children understand their experiences, as well as the experiences of others, and so it is through language that children connect this information with their own behavior.
\end{abstract}

Keywords: Early Childhood, self regulation, language

\begin{abstract}
Abstrak: Penelitian ini bertujuan untuk mendeskripsikan perkembangan regulasi diri anak usia 4-5 tahun di TK Dhamawanita Persatuan Pucang jajar. Penelitian ini merupakan penelitian kualitatif studi kasus pada anak usia 4-5 tahun. Teknik analisis data menggunakan model yang dikemukakan Miles and Huberman yang terdiri dari 3 tahapan: reduksi data, display data, dan verifikasi. Teknik pengumpulan data yang digunakan observasi, wawancara, dan dokumentasi. Hasil penelitian menunjukkan bahwa perkembangan regulasi diri berkembang secara bersamaan dengan kemampuan berbahasa. Bahasa dapat benar-benar memainkan peran penting dalam menentukan bagaimana anak-anak mengatur pikiran, emosi, dan perilaku mereka. Bahasa memfasilitasi internalisasi struktur sosial anak dan aturan melalui interaksi mereka dalam dunia sosial di sekitar mereka. Ketika anak-anak berinteraksi dengan orang lain, pemahaman mereka tentang perspektif orang lain dan harapan diperluas. Perspektif ini menunjukkan bahwa bahasa membantu anak-anak memahami pengalaman mereka, serta pengalaman orang lain, dan memang demikian melalui bahasa bahwa anak-anak menghubungkan informasi ini dengan perilaku mereka sendiri.
\end{abstract}

Kata Kunci: Anak Usia Dini, Regulasi Diri, Bahasa

Pembangunan sebuah negara ada dua hal yang sangat penting dan saling mempengaruhi yaitu pendidikan dan penganggulangan kemiskinan. Dua hal tersebut menjadi prioritas dalam pembangunan suatu negara. Namun, pencapaian kedua hal tersebut masih belum menunjukkan peningkatan yang signifikan, hal ini tampak bahwa kondisi kesejahteraan rakyat Indonesia sampai saat ini masih banyak yang berada dibawah garis kemiskinan. Dampak yang ditimbulkan oleh kemiskinan secara tidak langsung berpengaruh pada pendidikan. Banyak anak-anak Indonesia yang tidak memperoleh kesempatan pendidikan karena kondisi sosial keluarga.

Anak merupakan generasi penerus bangsa, sehingga diperlukan pendidikan sejak usia dini untuk menghasilkan gerasi yang berkualitas. Pendidikan anak usia dini akan memberikan pengasuhan, pendidikan dan pengajaran untuk mengembangkan keseluruhan aspek perkembangan anak dengan optimal.

Begitu juga dengan lembaga pendidikan anak usia dini TK Dharmawanita Persatuan Pucang Jajar Surabaya. TK Dharmawanita memberikan stimulasi untuk mengembangkan seluruh aspek perkembangan anak melalui 
Jurnal PG-PAUD Trunojoyo : Jurnal Pendidikan dan Pembelajaran Anak Usia Dini, Volume 5,

pembelajaran yang dilakukan. Namun ada beberapa permasalahan yang dialami, salah satunya masih ada beberapa anak yang keterampilan bahasanya rendah. Keterampilan bahasa akan mempengaruhi aktivitas anak sehari-hari dalam berinteraksi dengan lingkungan sekitar dan mempengaruhi keberhasilan anak di sekolah. Menurut Dickinson, McCabe, dan Essex, 2006 bahasa memiliki peranan penting dalam menentukan bagaimana anak-anak mengatur pikiran, emosi, dan perilaku mereka. Bahasa mampu memfasilitasi internalisasi sosial anak melalui interaksi mereka dalam dunia sosial di sekitar mereka. Disamping itu, perkembangan pengaturan diri (self regulation) anak-anak sangat erat terikat pada perkembangan bahasa mereka. Mereka menggunakan bahasa untuk mengatur perilaku mereka.

Paparan di atas dapat disimpulkan bahwa keterampilan bahasa yang dimiliki seorang anak memiliki peranan dalam regulasi diri anak. Penelitian ini bertujuan untuk menggambarkan peranan keterampilan bahasa terhadap regulasi diri anak usia dini.

\section{Regulasi Diri}

Menurut Bandura, regulasi diri adalah kemampuan mengontrol perilaku sendiri, indivdu memiliki kemampuan untuk mengontrol cara belajarnya dengan tiga tahap, mengembangkan langkah-langkah mengobservasi diri, menilai diri dan memberikan respon bagi dirinya sendiri.

Franken menjelaskan pengertian dari regulasi diri adalah sebagai berikut:

Self regulation refers to ability to make use of knowledge we have about the lawfulness of human behavior and use that knowledge to ac hieve goals tha we think are in our best interest or simply goods that will make us happy.

Pernyataan tersebut menjelaskan bahwa regulasi diri adalah kemampuan yang ada pada diri individu, yang mengacu pada kemampuan untuk menggunakan pengetahuan. Berkaitan dengan tujuan yang akan dicapai, dengan tetap meggunakan kesesuaian untuk membuat hidup yang bahagia, atau hidup teratur.
Schunk \& Zimmerman medefiniskan regulasi diri sebagai penggunaan suatu proses yang mengaktifasi pemikiran, perilaku dan perasaan yang terus menerus dalam upaya untuk mencapai tujuan yang telah ditetapkan. Regulasi diri digambarkan sebagai siklus, karena feedback dari tingkah laku sebelumnya digunakan untuk membuat penyesuaian dalam usahanya saat ini. Penyesuaian seperti itu diperlukan karena factorfaktor personal, tingkah laku, dan lingkungan yang secara konstan berubah selama proses belajar dan berperilaku.

Berdasarkan pemaparan pendapat tokoh diatas, dapat disimpulkan bahwa regulasi diri didefinisikan sebagai kemampuan seseorang untuk menampilkan serangkaian tindakan yang ditujukan untuk pencapaian target belajar dengan mengolah strategi-straegi dalam penggunaan kognisi, perilaku, dan afeksi/ emosional.

Regulasi diri (Self-regulation) pada anak mencakup kemampuan kontrol kognitif dan emosi anak usia dini. Berdasarkan beberapa penelitian tentang regulasi diri dari beberapa bidang yang berbeda menyebabkan ada beberapa definisi dari regulasi diri. Regulasi diri adalah kemampuan untuk mengendalikan diri sendiri, Mekanisme kontrol untuk kontrol emosi dan kognisi yang lebih kompleks. Regulasi diri juga merupakan kemampuan regulasi emosional. Misalnya, kemampuan mempertahankan kontrol yang kuat terhadap emosi. Namun, dari perspektif kognitif sering mendefinisikan pengaturan diri sebagai fungsi eksekutif dalam kemampuan kognitif, yang terdiri dari perhatian, memori kerja, dan kontrol yang bekerja bersama untuk memfasilitasi perilaku yang sesuai sasaran (Blair, Protzko, \& Ursache, 2011: 20$35)$.

Ketika anak-anak memasuki lingkungan sekolah awal, tuntutan baru dan kompleks ditempatkan pada keterampilan fungsi eksekutif mereka, yang berkembang pesat pada awal masa kanak-kanak. Menurut Faz, dkk (2002: 340347), Regulasi diri secara efektif memfasilitasi pembelajaran karena anak-anak yang memiliki perhatian yang kuat mampu mengendalikan, fokus, mengarahkan, dan mempertahankan perhatian mereka, dan mengabaikan gangguan/hambatan yang terjadi. Kapasitas yang terkait dengan perhatian ini sudah mulai 


\section{5, Nomor 2, Oktober 2018, hal $110-115$}

dikembangkan oleh anak-anak pada saat memasuki sekolah awal (paud) sekitar usia empat tahun. Memori kerja membutuhkan kemampuan menyimpan informasi penting dalam pikiran dan bertindak atas informasi tersebut. Bull \& Scerif, (2001: 273-293) mengemukakan bahwa memori kerja berpikir untuk meningkatkan pembelajaran anak-anak dengan memfasilitasi latihan dan transfer ke memori jangka panjang. Di kelas, memori kerja dapat memfasilitasi belajar karena memungkinkan anak-anak untuk mengingat dan menginstruksi saat melakukan sebuah tugas. Selain perhatian dan ingatan yang bekerja, fungsi eksekutif juga melibatkan kemampuan untuk menekan respon pra-potensial sebagai kontrol penghambatan. Ketiga ketrampilan ini dianggap sebagai komponen penting dari regulasi diri.

Regulasi diri merupakan komponen penting untuk kesiapan di sekolah. Perspektif ini mempertimbangkan aspek-aspek emosi dan kognitif dari pengaturan-diri sebagaimana adanya bekerja sama untuk memfasilitasi pengalaman belajar yang positif di lingkungan sekolah. Sebagai contoh, memperhatikan guru, mengingat instruksi, dan mengendalikan perilaku adalah semua bentuk dari regulasi diri. Kemampuan regulasi diri akan mempengaruhi kegiatan pembelajaran pada anak usia dini.

\section{Cara Mengukur Kemampuan Regulasi Diri}

Regulasi diri merupakan unsur penting keberhasilan anak di sekolah, sehingga ada cara terbaik untuk mengukurnya. Sama seperti istilah dan definisi yang digunakan tentang regulasi dir (self-regulation) yang sangat bervariasi, bahkan ada konsensus kurang tentang bagaimana keterampilan ini sebenarnya dinilai pada anakanak usia dini. Menurut Osborn, Butler, \& Morris, 1984, ada beberapa upaya yang berbeda dilakukan untuk menilai self-regulation. Misalnya, terkait dengan perhatian tugas-tugas umumnya termasuk tugas yang cocok atau menyalin, seperti Salinan Tes Desain atau tugas respons, seperti Kontinu Tes Kinerja. Sulit untuk merancang tugas yang menilai salah satu komponen dari self-regulation karena keterampilan ini saling berkaitan. Dengan demikian, langkah-langkah lain telah dikembangkan dengan pendekatan integratif. Dua jenis tindakan integratif yaitu penilaian guru dan lainnya, tindakan anak langsung yang lebih kompleks. McClelland, Morrison, \& Holmes, (2000: 307-329) mengemukakan alat utama yang digunakan untuk menilai regulasi diri anak adalah dengan hasil akademik mereka yang digunakan sebagai hasil pengukuran yang dilakukan guru. Beberapa penilaian guru seperti menilai temperamen atau sikap anak-anak dalam belajar. Sementara yang lain lebih diaplikasikan dan berupaya menurunkan peringkat pengaturan diri anak di lingkungan kelas. Ini diterapkan langkah-langkah termasuk item tentang bagaimana seorang anak mengingat dan mengikuti arahan, menyelesaikan tugas yang sulit, pergeseran antara kegiatan, dan mempertahankan perhatian. Penilaian anak yang dikelola secara individual, dapat berpotensi menangkap kapasitas anak untuk perilaku pengaturan diri sendiri dalam konteks kelas yang bermakna.

Selain penilaian guru, penilaian satu-satu yang lebih kompleks tentang pengaturan diri anak-anak telah dikembangkan. Langkahlangkah ini dimaksudkan untuk memanfaatkan perilaku dan keterampilan yang berhubungan dengan kelas yang sama selama aktivitas seperti dalam permainan. Permainan sebagai tes pengaturan diri, yang melibatkan semua komponen - perhatian, kontrol penghambatan, dan memori kerja. Baik penilaian guru dan penilaian anak langsung telah digunakan sebagai prediktor hubungan antara pengaturan diri di sekolah awal dan pencapaian akademik anakanak. Meskipun variasi dalam penilaian yang digunakan, bukti dari studi ini menunjukkan pengaturan diri sebagai prediktor penting pencapaian keberhasilan anak.

\section{Bahasa}

Bahasa adalah alat komunikasi atau penghubung antara individu satu dengan individu yang lain untuk pikiran, perasaan dan keinginannya. Anak yang dalam masa suka bermain berada dalam tahap menggabungkan pikiran dan bahasa sebagai satu kesatuan, ketika anak bermain dengan temannya mereka saling berkomunikasi dengan menggunakan bahasa anak dan itu berarti secara tidak langsung anak 
Jurnal PG-PAUD Trunojoyo : Jurnal Pendidikan dan Pembelajaran Anak Usia Dini, Volume 5,

belajar bahasa. Menurut Suhartono (2005), menyatakan bahwa dengan bantuan bahasa, anak tumbuh dari organisme biologis menjadi pribadi didalam kelompok. Pribadi itu berpikir, merasa, bersikap, berbuat serta memandang dunia dan kehidupan seperti masyarakat disekitarnya. Oleh sebah itu, bahasa merupakan alat perantara untuk berkomunikasi dengan orang lain menggunakan suatu sistem simbol dalam menyatakan pikiran, perasaan, serta keinginan yang diharapkan.

Pada anak usia 4-6 tahun, kemampuan bahasa yang harus dikuasai salah satunya adalah anak mampu menggunakan bahasa sebagai pemahaman bahasa pasif dan dapat berkomunikasi secara efektif yang bermanfaat untuk berfikir dan belajar dengan baik. Pengembangan bahasa pada anak usia 4-6 tahun menekankan pada perkembangan mendengar, berbicara, dan awal membaca/membaca awal. Perkembangan bahasa anak seperti yang telah dijelaskan oleh Vygotsky (dalam Masitoh 2003) yang menyatakan bahwa anak belajar bahasa dari orang dewasa secara kolaboratif, setelah itu diinternalisasikan dan secara sadar digunakan sebagai alat berfikir dan alat kontrol.

Kemampuan berbahasa anak usia dini akan mempengaruhi beberapa kemampuan yang lain. Seperti dalam aktifitas sehari-hari. Anak dalam bermain, mereka akan berinteraksi dengan teman-temannya atau orang-orang yang ada di lingkungan sekitarnya, secara otomatis mereka harus memiliki kemampuan berbahasa yang baik. Anak yang kemampuan bahasanya kurang baik akan kesulitan untuk mengungkapkan pemikiran dan keinginan kepada orang lain.

\section{METODE}

Penelitian ini menggunakan metode penelitian kualitatif dengan jenis penelitian studi kasus. Penelitian ini menggunakan penelitian studi kasus yang bertujuan untuk mendeskripsikan suatu gejala nyata atau situasi sosial yaitu peranan keterampilan bahasa terhadap regulasi diri anak-anak di TK Dharmaanita Pesatuan Pucang Jajar Surabaya.

Teknik pengumpulan data menggunakan teknik observasi, wawancara dan dokumentasi. Analisis data yang digunakan adalah model yang dikemukakan miles and huberman yang terdiri dari tiga langkah yaitu: reduksi data, penyajian data, dan verifikasi. Teknik pengecekan keabsahan data yang digunakan dalam penelitian ini adalah (1) ketekunan pengamatan, peneliti mengadakan penelitian langsung di lapangan dan menekuni hal-hal yang sedang diamati; (2) triangulasi, yang digunakan peneliti yaitu triangulasi sumber dan triangulasi metode. Triangulasi sumber, yaitu peneliti berupaya untuk mengecek keabsahan data yang didapatkan dari salah satu sumber dengan sumber yang lain.

\section{HASIL DAN PEMBAHASAN}

Dari hasil pengambilan data melalui catatan lapangan, wawancara dan dokumentasi memberikan fakta tentang regulasi diri pada anak di TK Dharmawanita Persatuan. Ada beberapa anak yang tidak mau terlibat dalam kelompok, ada yang mampu berinteraksi dengan semua teman dan ada yang cenderung menyendiri. Dari hasil pengamatan, kondisi anak-anak tersebut disebabkan karena kemampuan berbahasanya. Anak yang cenderung diam memang memiliki kemampuan bahasa yang kurang baik, sehingga anak cenderung kesulitan untuk berinteraksi dengan orang lain. Kemampuan bahasa menjadi point penting dalam kemampuan regulasi diri anak. Regulasi diri penting dalam mempersiapkan anak di sekolah di lingkungan masyarakat.

Selama masa kanak-kanak, perkembangan regulasi diri bersamaan dengan perkembangan yang kemampuan berbahasa, sehingga bahasa dapat benar-benar memainkan peranan penting dalam menentukan bagaimana anak-anak mengatur pikiran, emosi, dan perilaku mereka. Menurut Vygotsky, bahasa memfasilitasi internalisasi struktur sosial anak dan aturan melalui interaksi mereka dalam dunia sosial di sekitar mereka. Misalnya, bahasa yang dikembangkan anak-anak telah dikaitkan dengan perspektif dan pemahaman keadaan emosional atau sudut pandang orang lain. Perubahan perkembangan dianggap sebagai hasil bertahap dari interaksi antara anak dengan lingkungan sekitar dengan cara meningkatkan pengetahuan, kompetensi, dan berkomunikasi orang lain di lingkungan sosial, yang mendukung dan membimbing anak dalam menafsirkan pengalaman. 
Dengan kata lain, ketika anak-anak berinteraksi dengan orang lain, pemahaman mereka tentang perspektif orang lain dan harapan diperluas. Perspektif ini menunjukkan bahwa bahasa membantu anak-anak memahami pengalaman mereka, serta pengalaman orang lain, dan memang demikian melalui bahasa bahwa anak-anak menghubungkan informasi ini dengan perilaku mereka sendiri

Menurut Vygotsky, perkembangan pengaturan diri anak-anak sangat erat terikat pada perkembangan bahasa mereka. Mereka menggunakan bahasa (awalnya secara eksternal, kemudian secara internal) untuk mengatur perilaku mereka. Dalam penelitian ini, menemukan bahwa percakapan pribadi oleh anak-anak menghasilkan fungsi kognitif anak, membantu mereka bekerja dengan masalah yang sulit. Penggunaan percakapan pribadi oleh anakanak juga dapat memainkan peran penting dalam peralihan dari pengaturan diri eksternal ke internal. Dalam kegiatan pembelajaran di kelas, anak-anak lebih banyak terlibat dalam percakapan pribadi ketika mereka terlibat dalam open-ended kegiatan, seperti bermain fantasi.

Anak-anak dengan kemampuan bahasa yang lebih baik dapat mengembangkan strategi, seperti percakapan pribadi yang membantu mereka mengatur perilaku mereka. Pada saatnya, keterampilan pengaturan diri yang positif dapat meningkatkan kemampuan untuk menavigasi interaksi sosial dengan orang lain. Sebaliknya, anak-anak dengan kemampuan bahasa lemah mungkin mengalami kesulitan mengatur perilaku mereka dan berinteraksi dengan orang lain. Beberapa orang menyatakan bahwa kesulitan bahasa bisa menjadi faktor penyebab masalah perilaku, seperti agresi atau deficit perhatian gangguan hiperaktif. Hal ini menunjukkan kuatnya keterkaitan antara bahasa dan pengembangan regulasi diri pada anak.

Kemampuan bahasa telah terbukti dapat memprediksi perilaku bermasalah pada anak, seperti agresif dan kesulitan bersosialisasi dengan teman sebaya. Gallagher (1993) mengemukakan bahwa anak-anak dengan keterampilan bahasa rendah mungkin mengalami kesulitan berinteraksi dengan teman sebaya karena tindakan mereka sering disalah artikan atau tidak jelas. Kesulitan-kesulitan ini dapat mempengaruhi keseharian anak di sekolah dan mempengaruhi cara mereka berinteraksi orang lain dan dalam aktivitas belajar mengajar. Selanjutnya, pengalaman anak-anak yang frustrasi karena tidak dapat berkomunikasi secara efekti dengan teman sebaya dapat memiliki konsekuensi negatif untuk perilaku mereka.

\section{SIMPULAN}

Regulasi diri pada anak usia dini meliputi kemampuan anak untuk meraih kontrol terhadap emaosi dan perilaku sosial. Regulasi diri merupakan point penting dalam mempersiapkan anak untuk menjadi gerasi berkualitas yang mampu mengembangkan dan memposisikan diri pada situasi apapun. Regulasi diri dan kemampuan berbahasa berkembang secara bersama-sama. Anak yang memiliki kemampuan berbahasa yang baik cenderung memiliki kemampuan regulasi diri yang baik pula, begitu juga sebaliknya. Kemampuan berbahasa dapat digunakan untuk memprediksi perilaku bermasalah pada anak, anak yang kurang dalam kemampuan berbahasa cendung sulit untuk mengontrol emosi, sulit mengungkapkan pemikiran, dan keinginan. Dengan demikian dalam pengembangan regulasi diri seorang anak harus dibarengi dengan pengembangan kemampuan berbahasanya agar kemampuan regulasi diri juga berkembang dengan optimal.

\section{DAFTAR PUSTAKA}

Blair, C., Protzko, J., \& Ursache, A. 2011. Selfregulation and early literacy. In S. B. Neuman \& D. K. Dickinson (Eds.), Handbook of early literacy research (pp.). New York, NY: The Guilford Press

Bull, R., \& Scerif, G. 2001. Executive functioning as a predictor of children's mathematics ability: Inhibition, switching, and working memory. Developmental Neuropsychology, 19(3),

Fan, J., McCandliss, B. D., Sommer, T., Raz, A., \& Posner, M. I. 2002. Testing the efficiency and independence of 
Jurnal PG-PAUD Trunojoyo : Jurnal Pendidikan dan Pembelajaran Anak Usia Dini, Volume 5,

attentional networks. Journal of Cognitive Neuroscience, 14,.

Gallagher, T. M. 1993. Language skill and the development of social competence in school-age children. Language, Speech, and Hearing Services in Schools, 24

McClelland, M. M., Morrison, F. J., Holmes, D. L .2000. Children at risk for early academic problems: The role of learning-related social skills. Early Childhood Research Quarterly, 15,

Morrison, George S. 2012. Dasar-dasar Pendidikan Anak Usia Dini, Edisi ke lima. Jakarta: Indeks

Osborn, A. F., Butler, N. R., \& Morris, A. C. .1984. The social life of Britain's fiveyear-olds: A report of the child health and education study. London: Routledge \& Kegan Paul

Santrock, John W. 2009. Psikologi Pendidikan Educational psychology, Jakarta: selebah humanika. 